\title{
Factors Affecting Financial Literacy and Financial Behaviour of Investors in Pakistan
}

\author{
* Muhammad Junaid Khan, PhD Scholar (Corresponding Author) \\ ** Dr. Faheem Aslam, Assistant Professor \\ *** Syed Nisar-Ul-Mulk, PhD Scholar
}

\begin{abstract}
The main purpose of our study is to find out the impact of financial socialization, cognitive ability, and self-efficacy on financial literacy and financial behavior of investors in Pakistan. This study has used a non-probability convenience-based sampling technique for collecting the data. A total of 429 individual investors were analyzed with the help of structural equation modeling (SEM) through Smart PLS. The results of our research study suggested that the participation of female investors as compare to male investors is very low. The main results of the study showed that cognitive ability and self-efficacy have a significantly positive impact on financial literacy, but an insignificant impact of these two variables on financial behavior was found. Findings also suggested that the influence of financial socialization on financial literacy is insignificant, while financial behavior is positively influenced by financial socialization and financial literacy. In mediating analysis cognitive ability and self-efficacy have positively affected financial behavior, while financial socialization has an insignificant effect on financial behavior through financial literacy. This research study provides important implications for researchers and other policymakers. Policymakers can formulate policies regarding trainings to improve the financial literacy of investors. Researcher can further investigate these variables for other segments of the society.
\end{abstract}

Keywords: Financial Literacy, Financial Behaviour, Self-efficacy, Cognitive Ability, Financial Socialization

\section{Introduction}

In the modern world, financial literacy has been turned out to be a central focus of many organizations i.e. governments, banks, academia, and community interest groups (Zuhair et al., 2015). It is the understanding and processing of financial concepts, financial institutions, and financial products that lead to better financial decisions (Stolper \& Walter, 2017; Braunstein \& Welch, 2002; Hilgert et al., 2003; Bannier \& Neubert, 2016). It is the skill of making informed decisions by individuals and take effective actions of money management in current and future situations (U.S. Department of Treasury, 2008)

Statistics show that financial literacy is not even low in the developing countries but also in the advanced economies too (Morgan \& Trinh, 2019). For instance, the financial literacy level is very low in Italy followed by Japan and France but high in Germany, U.S, UK, and Canada in advanced countries. Similarly, it is found very low in Pakistan, India, and China; while the presentation of financial literacy is high in South Africa, the Russian Federation, and Brazil in emerging economies. It is also observed that females have very low financial literacy, while it is high for the male population globally (Murendo \& Mutsonziwa, 2017). Furthermore, it is concluded by Bruhn et al. (2013) that financial literacy reaches its highest point in middle age, while the same remains lower in younger age. Most significantly, it is suggested by the work of Fornero and Monticone (2011) that investors have no idea about the basic financial concepts and fail to perform efficient and effective financial activities. These differences have motivated us to further investigate this issue whether such circumstances develop due to the low level of financial literacy of investors in the context of Pakistan.

\footnotetext{
* Department of Management Sciences, COMSATS University, Islamabad Email: muhmmadutmani@yahoo.com

** Department of Management Sciences, COMSATS University, Islamabad

Email: fahimparacha@gmail.com

*** Department of Management Sciences, University of Swabi, Khyber Pakhtunkhwa
} 
It is crucial to explore such elements that affect the financial literacy of individuals. For example, cognitive ability, and financial socialization agents (parents) play important role in the accomplishment of financial literacy (Skagerlund, 2018; Shim et al., 2010; Tang et al., 2015) and ultimately financial behavior (Gudmunson \& Danes, 2011). According to the study of Pandey et al. (2020), peer influence should be investigated to get better results on financial literacy. In this regard, other researchers investigated that self-efficacy has been getting more attention in the achievement of financial literacy (Serido et al., 2013; Skagerlund et al., 2018). So, the main purpose of our study is to find the impact of these factors i.e social (peers), cognitive ability, and self-efficacy on financial literacy and then its whole impact on the financial behavior of investors in Pakistan.

\section{Objective of the Study}

To find out the impact of financial socialization, cognitive ability, and self-efficacy on financial literacy and financial behavior of investors in Pakistan.

\section{Literature Review}

This research work is supported by the theory of planned behavior (Ajzen, 1991) and consumer socialization theory (Moschis \& Churchill, 1978). The theory of planned behavior proposes that individuals perform similar behavior as performed by other individuals, while the theory of consumer socialization imagines that young people always develop their skills, knowledge, and attitudes.

\section{Financial Literacy and Demographic Variables}

Financial literacy is strongly predicted by age (Morgan \& Trinh, 2019), gender (Murendo \& Mutsonziwa, 2017), income (Dewanty \& Isbanah, 2018), education level (Garcia \& Tessada, 2013), marital status (Jariwala, 2013), employment status (Morgan \& Trinh, 2019), and living arrangements (Lusardi \& Mitchell, 2011). More specifically, as the income and age of the individual increases then financial literacy is also increased with time (Lusardi \& Tufano, 2009). Monticone (2010) investigated that any individual with a higher level of income invest more in the acquisition of financial knowledge. Similarly, individuals having a low level of education may lead to low financial literacy levels (Lusardi, 2003). Additionally, previous studies mentioned that the level of financial literacy is higher in married as compared to unmarried (Brown \& Graf, 2013). Furthermore, individuals can better plan their financial life due to steady income and working arrangements (Calamato, 2010).

\section{Financial Literacy, Cognitive Ability and Financial Behaviour}

Previous research studies have investigated that the important determinant of financial literacy is cognitive ability (Murillo et al., 2020). Lusardi et al. (2017) has observed that financial literacy is just like an investment in human capital investment in which additional financial information is achieved by the individual. To achieve such knowledge the individuals, go through some cost i.e time and money. Cognitive ability shows the ability to process mental information for achieving the results. Broadly speaking, it is the basic determinant of such cost of gaining additional knowledge of finance. It was also suggested by Delavande et al. (2008) that cognitive ability is thought to be an efficient factor that examines the input to productivity in the construction of extra financial literacy. As the level of stock of cognitive ability increases then it leads to efficient investment in financial literacy vice versa. Thus, a positive association is found here between financial literacy and cognitive ability. Other studies described that cognitive abilities predict sound financial behavior of individual's i.e wealth, retirement income, and key dimensions of retirement expectation (Banks et al., 2010; Hsu \& Willis, 2013; Korniotis \& Kumar, 2011). Few studies have investigated the relationship between cognitive ability and financial literacy for other segments of the society. But this time the focus will be investors which has not been studied in the Pakistani context.

\section{Financial Literacy, Financial Socialization and Financial Behaviour}

Financial socialization is the practice of getting skills, knowledge, and attitudes from different peoples or environments to enhance their role in the financial market (Ward, 1974). It can also be defined as the social process of transmitting various consumer characteristics from socialization agents. These socialization agents are media, schools, peers, and family members. Hira et al. (2013) found that parents are important socialization agents of investors, household net worth, and influencing investment regulators. More specifically, the involvement of parents in starting investment regularly at an early age is very important as well as continuing the similar with increased involvement in later years. It was also concluded by Grohmann et al. (2015) that the school-related variables and financial 
literacy has a direct impact on financial behavior. They performed a mediation analysis and resulted that both the school and family variables positively affected adult's financial literacy. In simple terms, the financial socialization approach may develop an understanding of financial literacy (Gudmunson \& Danes, 2011; Sohn et al., 2012). Mostly, individuals interact with different financial socialization channels such as media, friends, education, and parents then higher financial literacy is achieved, and having higher financial literacy subsequently influences the individual financial behavior (Sundarasen et al., 2016). This variable is also studied for mostly for students and other segments of the society. But little is known about its impact on financial literacy for investors, especially in Pakistan.

\section{Financial Literacy, Self-efficacy, and Financial Behaviour}

Self-efficacy is the ability of an individual to achieve a given task or reach a specific objective or goal in the future. It can also be elaborated as the belief of doing certain things by individuals in their life. Individuals have successfully reduced fees on investment tasks and planned very well for retirement due to their confidence (Parker et al., 2012). It was analyzed that confidence and knowledge have a positive correlation in national sample recruited through the American Life Panel about financial decisions i.e. investing and saving for retirement of individuals. Lusardi and Tufano (2015) also examined that mostly older people perform better in actual financial behavior and financial literacy due to their high confidence. But Farrell et al. (2016) analyzed that Australian women are selfconfident in their financial decision-making capabilities i.e. holding less debt-related products and most probably hold saving and investment products. This variable is necessary to include in the study because self-confident investors always perform better in any financial activity when they have financial knowledge.

\section{Conceptual Framework}

Previous research studies have examined that financial literacy is influenced by self-efficacy (Lusardi \& Tufano, 2009), financial socialization (Ameliawati \& Setiyani, 2018), and cognitive ability (Skagerlund et al., 2018). The findings of Grohmann (2018) examined that financial literacy itself has an impact on financial behavior. So, it is expected that cognitive ability, self-efficacy, and financial socialization affect financial behavior. The conceptual framework of the study is provided as:

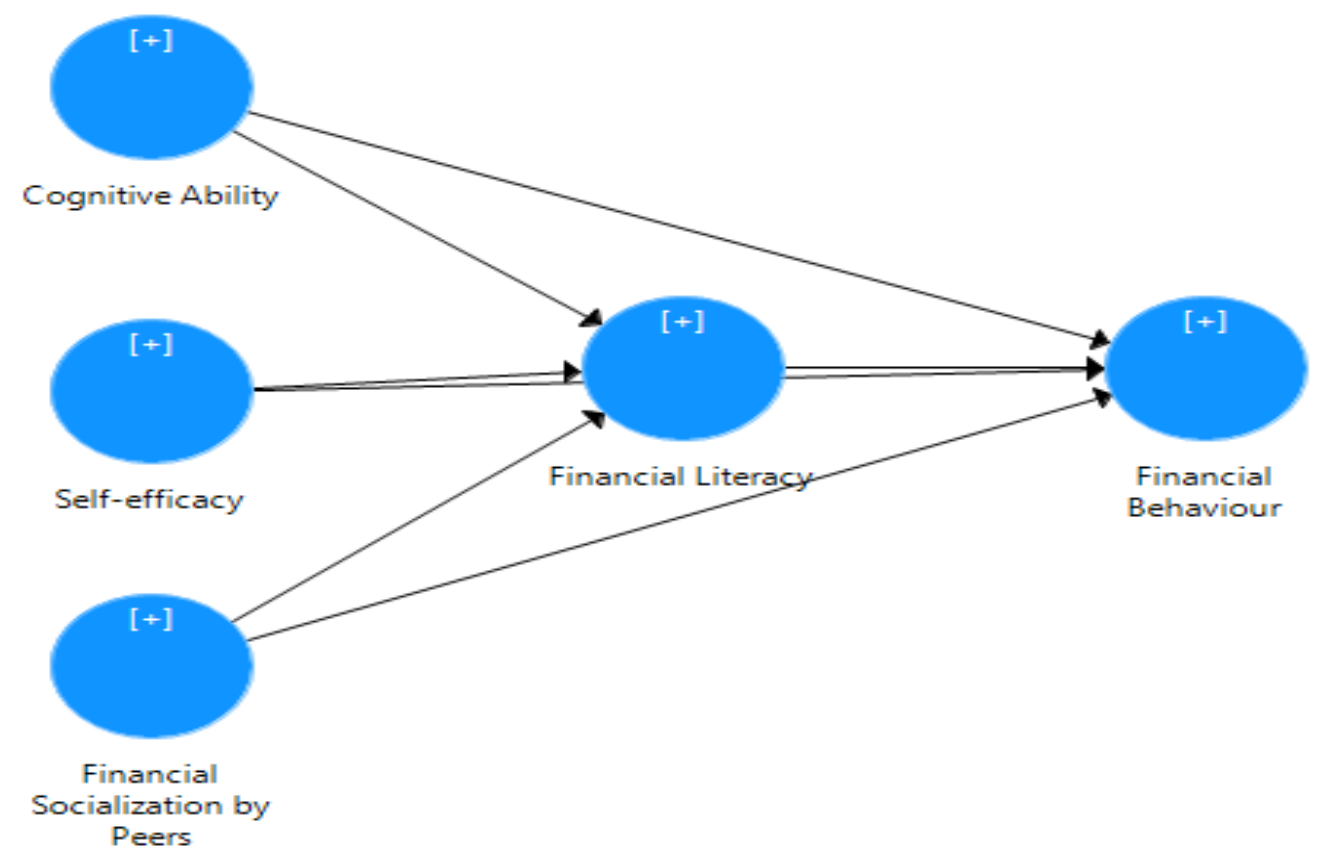

Figure 1 Conceptual Framework

\section{Methodology}

This study has used a deductive approach and exploratory in nature. Data were collected from different cities of Pakistan. A total of 550 online questionnaires were shared with individual investors of the stock market of Pakistan; in which 429 respondents have returned their questionnaires incomplete form. The response rate was approximately $78 \%$. Convenience based non-probability sampling technique was used for collecting the data. 


\section{Measurement of Variables}

Financial Behaviour (FB): This variable is the dependent variable and measured from "strongly disagree" to "strongly agree" with a 5-Likert scale. Seven items were taken from different studies i.e. Rai et al., (2019), Potrich, Vieira and Kirch (2018), and Shockey (2002) to measure this variable.

Financial Literacy (FL): This variable is a mediating variable and measured from "strongly disagree" (1) to "strongly agree" (5) with 5-Likert scale. Six items were taken from Xia et al. (2014) and Grohmann (2018) and modified accordingly.

Financial Socialization (FS): The measurement items of peers' financial socialization were adapted from Shim et al., (2010). A total of four items were taken from such a study and modified from "strongly disagree" to "strongly agree" with a 5-Likert scale.

Cognitive Ability (CA): To measure cognitive ability we have adopted four items from Fagerlin et al., (2007). Such items were measured with a 5-point Likert scale from "Poor" to "Excellent".

Self-Efficacy (SE): Self-efficacy subset of items taken from the previous studies (Skagerlund et al., 2018; Forbes \& Kara, 2010; Danes and Haberman, 2007). Such items were measured from "strongly disagree" to "strongly agree" with a 5-Likert scale.

\section{Data Analysis}

Mostly, the researcher has used partial least square structural equation modeling with Smart PLS (version.3.2.4) software (Ringle et al., 2020). This study has also used the same approach for data analysis. Before continuing to the results of structural equation modeling, we will give respondents' profiles for the general overview.

\section{Respondents' Profile}

The profile of respondents is provided in Table 1. It has briefly discussed the gender, monthly income, marital status, employment status, educational status, age, and living arrangements according to their frequencies and percentages.

\section{Table 1: Respondents' Profile ( $n=429)$}

\begin{tabular}{|c|c|c|c|}
\hline & & Frequency & Percent \\
\hline \multirow[t]{2}{*}{ Gender } & Male & 365 & $85.1 \%$ \\
\hline & Female & 64 & $14.9 \%$ \\
\hline \multirow[t]{6}{*}{ Age } & 16 to 25 years & 72 & $16.8 \%$ \\
\hline & 26 to 35 years & 174 & $40.6 \%$ \\
\hline & 36 to 45 years & 101 & $23.5 \%$ \\
\hline & 46 to 55 years & 57 & $13.3 \%$ \\
\hline & 56 to 65 years & 22 & $5.1 \%$ \\
\hline & $66+$ years & 3 & $0.7 \%$ \\
\hline \multirow[t]{5}{*}{ Employment Status } & Self-employed & 104 & $24.2 \%$ \\
\hline & Full-time worker & 185 & $43.1 \%$ \\
\hline & Part-time worker & 26 & $6.1 \%$ \\
\hline & Retired & 12 & $2.8 \%$ \\
\hline & Government employee & 102 & $23.8 \%$ \\
\hline \multirow[t]{3}{*}{ Educational Status } & Intermediate & 35 & $8.2 \%$ \\
\hline & Undergraduate & 182 & $42.4 \%$ \\
\hline & Graduate/Post-Graduate & 212 & $49.4 \%$ \\
\hline \multirow[t]{4}{*}{ Marital Status } & Single & 147 & $34.3 \%$ \\
\hline & Married & 270 & $62.9 \%$ \\
\hline & Divorced & 6 & $1.4 \%$ \\
\hline & Widow/Widower & 6 & $1.4 \%$ \\
\hline \multirow[t]{7}{*}{ Monthly Income } & $15,000-30,000$ & 82 & $19.1 \%$ \\
\hline & $31,000-45,000$ & 96 & $22.4 \%$ \\
\hline & $46000-60000$ & 70 & $16.3 \%$ \\
\hline & $61000-75000$ & 64 & $14.9 \%$ \\
\hline & $76000-90000$ & 53 & $12.4 \%$ \\
\hline & $91,000-120,000$ & 40 & $9.3 \%$ \\
\hline & $120,000-150,000$ & 24 & $5.6 \%$ \\
\hline \multirow{4}{*}{ Living Arrangements } & Live Alone & 36 & $8.4 \%$ \\
\hline & Living with spouse/partner & 135 & $31.5 \%$ \\
\hline & Live parents (live in my parents' home) & 72 & $16.7 \%$ \\
\hline & Live other (live with other family, friends, or roommates) & 186 & $43.4 \%$ \\
\hline
\end{tabular}




\section{Structural Equation Modelling}

Structural equation modeling best deal with different items and their respected constructs and then the relationship of these constructs with each other (Kline, 2015). Structural equation modeling has two important aspects i.e structural model and measurement model. Each of these models is given in a more detailed explanation.

\section{1) Evaluation of Measurement Models}

The measurement model consists of discriminant validity, convergent validity, and internal consistency of constructs.

(i) Individual indicator reliability

Individual indicator reliability is the correlations of each item or indicator with relevant construct (Hair et al., 2014). According to Fornell and Larcker (1981), the value of outer loadings is considered as individual indicator reliability, which should be 0.708 or more. In Table 2 it is suggested that all values of items are more than 0.708 , which shows the individual indicator reliability of items of each construct.

\section{Table 2: Individual Indicators Reliability}

\begin{tabular}{|c|c|c|c|c|c|}
\hline Items & CA & FB & FL & FS & SE \\
\hline C1 & 0.770 & & & & \\
\hline C2 & 0.837 & & & & \\
\hline C3 & 0.857 & & & & \\
\hline $\mathrm{C} 4$ & 0.850 & & & & \\
\hline FB1 & & 0.803 & & & \\
\hline FB2 & & 0.730 & & & \\
\hline FB3 & & 0.715 & & & \\
\hline FB4 & & 0.778 & & & \\
\hline FB5 & & 0.799 & & & \\
\hline FB6 & & 0.726 & & & \\
\hline FB7 & & 0.821 & & & \\
\hline FL1 & & & 0.724 & & \\
\hline FL2 & & & 0.799 & & \\
\hline FL3 & & & 0.756 & & \\
\hline FL4 & & & 0.806 & & \\
\hline FL5 & & & 0.803 & & \\
\hline FL6 & & & 0.768 & & \\
\hline PE1 & & & & 0.834 & \\
\hline PE2 & & & & 0.809 & \\
\hline PE3 & & & & 0.752 & \\
\hline PE4 & & & & 0.713 & \\
\hline SE1 & & & & & 0.709 \\
\hline SE2 & & & & & 0.760 \\
\hline SE3 & & & & & 0.900 \\
\hline SE4 & & & & & 0.878 \\
\hline SE5 & & & & & 0.859 \\
\hline
\end{tabular}

(ii) Internal Consistency Reliability

Internal consistency reliability is used to check how well the assigned indicators measure a construct. Composite reliability scores and Cronbach's alpha are used for the internal consistency reliability of a variable. The values of these two terms must exceed the threshold value of 0.7 . In our study, the values of these two terms are higher that shows the internal consistency reliability of constructs (Hair et al., 2014).

Table 3: Internal Consistency Reliability

\begin{tabular}{llr}
\hline Construct & Cronbach's Alpha & Composite Reliability (CR) \\
\hline CA & 0.848 & 0.898 \\
FB & 0.885 & 0.91 \\
FL & 0.869 & 0.901 \\
FS & 0.786 & 0.86 \\
SE & 0.881 & 0.913 \\
\hline
\end{tabular}


The extent of one indicator to be correlated with another indicator of the same construct is called convergent validity. The value of the average variance extracted (AVE) is used for convergent validity and its value should be higher than 0.5 (Hair et al., 2014). In Table 4 the values of AVE are greater than 0.5 , which shows convergent validity (see Table 4).

\section{Table 4: Convergent Validity}

\begin{tabular}{lr}
\hline Constructs & Average Variance Extracted (AVE) \\
\hline CA & 0.687 \\
FB & 0.590 \\
FL & 0.603 \\
FS & 0.606 \\
SE & 0.680 \\
\hline
\end{tabular}

(iv) Discriminant Validity

Discriminant validity is the degree of difference of one construct from another construct in the model (Hair et al., 2017). It can be tested through three methods i.e Cross Loadings, HeterotraitMonotrait ratio (HTMT), and Fornell-Larcker criterion. Here we have used the HTMT ratio for the discriminant validity of constructs because it is the best method (Henseler et al., 2015). HTMT values are less than the threshold value of 0.9 , which shows the discriminant validity of constructs (see Table 5).

Table 5: Heterotrait-Monotrait Ration (HTMT)

\begin{tabular}{lccccc} 
Construct & CA & FB & FL & FS & SE \\
\hline CA & & & & & \\
FB & 0.120 & & & & \\
FL & 0.509 & 0.259 & & & \\
FS & 0.594 & 0.196 & 0.354 & 0.433 & \\
SE & 0.584 & 0.181 & 0.685 &
\end{tabular}

\section{2) Evaluation of Structural Model}

In the structural model, the researcher finds out the relationship between constructs (Hair et al., 2014). It consists of path coefficients, mediation analysis, effect size, predictive relevance, and model fit.

(i) Path Coefficients

In the path coefficient, the associations among different constructs of the study are investigated. It shows the strength of the association among two constructs (Wixom and Watson, 2001). Please see Table 6.

Table 6: Path Coefficients

\begin{tabular}{lllllr}
\hline Constructs & $\begin{array}{l}\text { Original } \\
\text { Sample }\end{array}$ & Sample Mean & $\begin{array}{l}\text { Standard } \\
\text { Deviation }\end{array}$ & T-Statistics & P-Values \\
\hline CA -> FB & -0.021 & -0.018 & 0.060 & 0.346 & 0.730 \\
CA -> FL & 0.191 & 0.190 & 0.056 & 3.411 & 0.001 \\
FL -> FB & 0.201 & 0.200 & 0.063 & 3.167 & 0.002 \\
FS -> FB & 0.248 & 0.252 & 0.054 & 4.607 & 0.000 \\
FS -> FL & 0.039 & 0.043 & 0.049 & 0.794 & 0.428 \\
SE -> FB & -0.031 & -0.032 & 0.066 & 0.476 & 0.634 \\
SE -> FL & 0.506 & 0.505 & 0.050 & 10.149 & 0.000 \\
\hline
\end{tabular}

It is suggested from (Table 6$)$ that the impact of CA $(\beta=-0.021, p>0.10)$ and SE $(\beta=-0.031$, $\mathrm{p}>0.10)$ on FB is insignificant, while FL $(\beta=0.201, \mathrm{p}<0.01)$ and FS $(\beta=0.248, \mathrm{p}<0.01)$ have positive influence on FB of investors. Similarly, the influence of CA $(\beta=0.191, p<0.01)$ and SE $(\beta=0.506$, $p<0.01)$ is positively significant in FL. The impact of FS $(\beta=0.039, p>0.10)$ was found insignificant on the financial literacy of investors.

If we talk about the control variables of the study then age and income have a significant positive impact on financial behavior, while negative significant impact by gender and education on financial behavior. The impact of employment status, marital status, and living arrangements on financial behavior is insignificant.

Furthermore, financial literacy is insignificantly influenced by marital status, living arrangements, employment status. But significantly negative influence of education on financial 
literacy was found in our study. Moreover, gender and income have a significantly positive effect on financial literacy.

(ii) Mediation Analysis

In mediation analysis, the impact of the independent variable is investigated on the dependent variable through the mediation of another variable (Hair et al., 2017). In our study, FL is a mediating variable that provides the basis of mediation between FS, SE, CA, and FB. The significant positive influence of CA $(\beta=0.038, p<0.05)$ and SE $(\beta=0.101, p<0.01)$ was found on FB, while FS $(\beta=0.008$, $\mathrm{p}>0.10$ ) has an insignificant effect on FB through FL (see Table 7).

\begin{tabular}{lrrrrr}
\multicolumn{1}{l}{ Table 7: Specific Indirect Effect } & & & \\
\hline Constructs & $\begin{array}{r}\text { Original } \\
\text { Sample }\end{array}$ & Sample Mean & $\begin{array}{r}\text { Standard } \\
\text { Deviation }\end{array}$ & T-Statistics & P-Values \\
\hline CA -> FL -> FB & 0.038 & 0.037 & 0.015 & 2.553 & 0.011 \\
FS -> FL -> FB & 0.008 & 0.009 & 0.011 & 0.711 & 0.477 \\
SE -> FL -> FB & 0.101 & 0.101 & 0.034 & 2.959 & 0.003 \\
\hline
\end{tabular}

The total effects of exogenous constructs on FB of the respondents are also provided here. It is the sum of the indirect effect and the direct effect of any construct. In this case, the total effect of CA $(\beta=0.017, p>0.10)$ and SE $(\beta=0.070, p>0.10)$ are insignificant for FB, while the FS $(\beta=0.256$, $\mathrm{p}<0.01$ ) has significant influence on FB (see Table 8).

Table 8: Total Effects

\begin{tabular}{lllllr}
\hline Constructs & $\begin{array}{l}\text { Original } \\
\text { Sample }\end{array}$ & Sample Mean & $\begin{array}{l}\text { Standard } \\
\text { Deviation }\end{array}$ & T-Statistics & P-Values \\
\hline CA -> FB & 0.017 & 0.019 & 0.061 & 0.286 & 0.775 \\
FS -> FB & 0.256 & 0.261 & 0.053 & 4.790 & 0.000 \\
SE -> FB & 0.070 & 0.069 & 0.053 & 1.310 & 0.191 \\
\hline
\end{tabular}

(iii) Coefficient of Determination (R2 value)

The predictive accuracy of the structural model is tested by the coefficient of determination

(R2). It can be generated as the squared correlation among predictive and actual values of specific endogenous constructs (Hair et al., 2014). R-square value of FB is $19.7 \%$ and $44 \%$ of FL, suggesting that $19.7 \%$ of variation is occurred in FB due to FL, FS, CA, and SE, while the remaining variation is brought in this variable due to some other variables that are not taken in the study. Similarly, $44 \%$ of variation in financial literacy occurs due to FS, CA, and SE. So, it is concluded that both models' predictive accuracy is moderate (Chin, 1998). Furthermore, the value of adjusted R-square is increased by adding a new variable to the model. Its value is always lower than R-square and suitable for evaluating model fit.

Table 9: Predictive Accuracy

\begin{tabular}{llr}
\hline Constructs & R-Square & R-Square Adjusted \\
\hline FB & 0.197 & 0.175 \\
FL & 0.44 & 0.426 \\
\hline
\end{tabular}

(iv) Effect Size (f2)

The effect size (f2) demonstrates the impact of each independent variable on the dependent variable (Hair et al., 2014). The effect size of all variables i.e. FL (0.028), FS (0.051), and SE (0.001) on FB is smaller. The effect size of CA (0.041) and FS (0.002) on FL is also smaller, while the medium effect size of SE (0.328) on FL is found (Cohen, 1988) (see Table 10).

Table 10: Effect Size (f2)

\begin{tabular}{llr}
\hline Construct & FB & FL \\
\hline CA & 0.000 & 0.041 \\
FB & & \\
FL & 0.028 & 0.002 \\
FS & 0.051 & 0.328 \\
SE & 0.001 & \\
\hline
\end{tabular}

(v) Model Fit

Model fit is achieved from the standardized difference of observed correlation and predicted correlation. In this study, the value of Standardized Root Mean Square Residual (SRMR, 0.064) is less than 0.08 value, which points out the fit of a good model (Henseler et al., 2016). 


\section{(vi) Assessing Q2 Values}

The Stone-Geisser Q2 value is employed as for the relevance to predict each endogenous variable (Stone, 1974; Geisser, 1974). In this study, the Q2 values of FL and FB are 0.235 and 0.104, respectively. All the values of Q2 for FB and FL are above zero (0) in this study that shows the model has predictive relevance of our endogenous variables (see Table 11).

Table 11: Cross-validated redundancy $($ Q2)

\begin{tabular}{lr}
\hline Constructs & $\mathbf{Q}^{2}$ \\
\hline FB & 0.104 \\
FL & 0.235 \\
\hline
\end{tabular}

Discussion and Conclusion

Financial literacy is believed to be the most significant element of the modern financial era. This study found a significant positive impact of gender of respondents and income on financial literacy. The same results were also produced by Murendo and Mutsonziwa (2017), and Dewanty and Isbanah (2018) for gender and income relationship with financial literacy, while the effect on financial literacy by education was found negative for investors in Pakistan. The influence of age, employment status, living arrangements, and marital status is insignificant here (Morgan \& Trinh, 2019; Jariwala, 2013; Pires and Quelhas, 2015). Similarly, age and income have a significantly positive impact on the financial behavior of investors; while the influence of living arrangements, marital status, and employment status was found insignificant. Moreover, financial behavior is negatively influenced by gender and education. Such results were also produced by Lusardi \& Mitchell (2008) for gender differences.

The impact of our main variables i.e cognitive ability, financial socialization, and selfefficacy on financial literacy was observed. Our outcomes illustrated that financial literacy is insignificantly influenced by financial socialization. Similar results were produced by Jorgensen and Savla (2010). Additionally, financial literacy is positively influenced by cognitive ability and selfefficacy. Also, these results are held by Hastings et al. (2013) and Skagerlund et al., (2018).

The results of the main variables of our study show that financial behavior is insignificantly influenced by cognitive ability and self-efficacy. Tang et al, (2015) presented the same view for the association between cognitive ability and financial behavior in their research study. It was also investigated that financial literacy and financial socialization has a significantly positive impact on financial behavior. The results of our study are in line with the findings of Grohmann et al., (2015) and Lachance and Legault (2007).

Finally, our results suggested that self-efficacy and cognitive ability positively manipulate the financial behavior of investors through the financial literacy of investors in Pakistan, while financial socialization does not influence financial behavior through financial literacy.

\section{Policy Implications}

This study provides some insights for policymakers and researchers that must be further investigated. Based on this study policymakers may make policies to enhance the level of financial literacy among investors and as well as other segments of the society. Similarly, gender differences also prevail in the stock market of Pakistan. Policymakers should make some policies to minimize these gender differences among investors.

Researchers can further investigate the financial literacy and financial behavior through their one by one item relationship. Also, they can scrutinize the effect of other variables on financial literacy and financial behavior which are not taken in our research study.

\section{Future Research}

Future research studies can be carried out for other segments of the society like managers, bankers, brokers, Govt employees, school, and college teachers, and finally the students. It would be also beneficial to educate these segments with financial concepts, after educating the respondents, are then investigated for their financial literacy levels.

\section{References}

Ajzen, I. (1991). The theory of planned behavior. Organizational behavior and human decision processes, 50(2), 179-211.

Ameliawati, M., \& Setiyani, R. (2018). The influence of financial attitude, financial socialization, and financial experience to financial management behavior with financial literacy as the mediation variable. KnE Social Sciences, 811-832. 
Arora, M., \& Kumari, S. (2015). Risk-taking in financial decisions as a function of age, gender: mediating role of loss aversion and regret. International Journal of Applied Psychology, 5(4), 83-89.

Banks, J., O'Dea, C., \& Oldfield, Z. (2010). Cognitive function, numeracy, and retirement saving trajectories. The Economic Journal, 120(548), F381-F410.

Bannier, C. E., \& Neubert, M. (2016). Gender differences in financial risk-taking: The role of financial literacy and risk tolerance. Economics Letters, 145, 130-135.

Braunstein, S., \& Welch, C. (2002). Financial literacy: An overview of practice, research, and policy. Fed. Res. Bull., 88, 445.

Brown, M., \& Graf, R. (2013). Financial literacy and retirement planning in Switzerland. Numeracy, 6(2), 2-23.

Bruhn, M., Ibarra, G. L., \& McKenzie, D. (2013). Why is voluntary financial education so unpopular? Experimental evidence from Mexico. The World Bank.

Calamato, M. P. (2010). Learning financial literacy in the family.

Chin, W. W. (1998). The partial least squares approach to structural equation modeling. Modern methods for business research, 295(2), 295-336.

Cohen, J. (1988). Statistical power analysis for the behavioral sciences New York. NY: Academic.

Danes, S. M., \& Haberman, H. (2007). Teen financial knowledge, self-efficacy, and behavior: A gendered view. Journal of Financial Counseling and Planning, 18(2).

Delavande, A., Rohwedder, S., \& Willis, R. J. (2008). Preparation for retirement, financial literacy, and cognitive resources. Michigan Retirement Research Center Research Paper, (2008-190).

Dewanty, N., \& Isbanah, Y. (2018). Determinant of the Financial Literacy: Case Study on Career Woman in Indonesia. ETIKONOMI, 17(2), 285-296.

Fagerlin, A., Zikmund-Fisher, B. J., Ubel, P. A., Jankovic, A., Derry, H. A., \& Smith, D. M. (2007). Measuring numeracy without a math test: development of the Subjective Numeracy Scale. Medical Decision Making, 27(5), 672-680.

Farrell, L., Fry, T. R., \& Risse, L. (2016). The significance of financial self-efficacy in explaining women's finance behavior. Journal of Economic Psychology, 54, 85-99.

Forbes, J., \& Kara, S. M. (2010). Confidence mediates how investment knowledge influences investing self-efficacy. Journal of economic psychology, 31(3), 435-443.

Fornell, C., \& Larcker, D. F. (1981). Structural equation models with unobservable variables and measurement error: Algebra and statistics.

García, R., \& Tessada, J. (2013). The Effect of Education on Financial Market Participation: Evidence from Chile.

Garg, N., \& Singh, S. (2018). Financial literacy among youth. International Journal of sociaL economics.

Geisser, S. (1974). A predictive approach to the random effect model. Biometrika, 61(1), 101-107.

Grohmann, A. (2018). Financial literacy and financial behavior: Evidence from the emerging Asian middle class. Pacific-Basin Finance Journal, 48, 129-143.

Grohmann, A., Kouwenberg, R., \& Menkhoff, L. (2015). Childhood roots of financial literacy. Journal of Economic Psychology, 51, 114-133.

Gudmunson, C. G., \& Danes, S. M. (2011). Family financial socialization: Theory and critical review. Journal of family and economic issues, 32(4), 644-667.

Hair Jr, J. F., Matthews, L. M., Matthews, R. L., \& Sarstedt, M. (2017). PLS-SEM or CB-SEM: updated guidelines on which method to use. International Journal of Multivariate Data Analysis, 1(2), 107-123.

Hair Jr, J. F., Sarstedt, M., Hopkins, L., \& Kuppelwieser, V. G. (2014). Partial least squares structural equation modeling (PLS-SEM). European business review.

Hastings, J. S., Madrian, B. C., \& Skimmyhorn, W. L. (2013). Financial literacy, financial education, and economic outcomes.

Henseler, J., Ringle, C. M., \& Sarstedt, M. (2015). A new criterion for assessing discriminant validity in variance-based structural equation modeling. Journal of the academy of marketing science, 43(1), 115-135. 
Hilgert, M. A., Hogarth, J. M., \& Beverly, S. G. (2003). Household financial management: The connection between knowledge and behavior. Fed. Res. Bull., 89, 309.

Hira, T. K., Sabri, M. F., \& Loibl, C. (2013). Financial socialization's impact on investment orientation and household net worth. International Journal of Consumer Studies, 37(1), 29-35.

Hsu, J. W., \& Willis, R. (2013). Dementia risk and financial decision making by older households: The impact of information. Journal of Human Capital, 7(4), 340-377.

Jariwala, H. (2014). To study the level of financial literacy and its impact on investment decision-an in-depth analysis of investors in Gujarat State.

Jorgensen, B. L., \& Savla, J. (2010). Financial literacy of young adults: The importance of parental socialization. Family Relations, 59(4), 465-478.

Kline, R. B. (2015). Principles and practice of structural equation modeling. Guilford publications.

Korniotis, G. M., \& Kumar, A. (2011). Do older investors make better investment decisions? The Review of Economics and Statistics, 93(1), 244-265.

Kramer, M. M. (2016). Financial literacy, confidence, and financial advice seeking. Journal of Economic Behavior \& Organization, 131, 198-217.

Kubilay, B., \& Bayrakdaroglu, A. (2016). An empirical research on investor biases in financial decision-making, financial risk tolerance, and financial personality. International Journal of Financial Research, 7(2), 171-182.

Lachance, M. J., \& Legault, F. (2007). College students' consumer competence: Identifying the socialization sources. Journal of Research for Consumers, (13), 1.

Lusardi, A. (2003). Saving and the effectiveness of financial education. Pension Research Council WP2003-14.

Lusardi, A., \& Mitchell, O. S. (2011). Financial literacy around the world: an overview (No. w17107). National Bureau of Economic Research.

Lusardi, A., \& Mitchell, O. S. (2008). Planning and financial literacy: How do women fare? American Economic Review, 98(2), 413-17.

Lusardi, A., Samek, A., Kapteyn, A., Glinert, L., Hung, A., \& Heinberg, A. (2017). Visual tools and narratives: New ways to improve financial literacy. Journal of Pension Economics \& Finance, 16(3), 297-323.

Lusardi, A., Schneider, D., \& Tufano, P. (2015). The economic crisis and medical care use: comparative evidence from five high-income countries. Social Science Quarterly, 96(1), 202213.

Lusardi, A., \& Tufano, P. (2009). Debt literacy, financial experiences, and overindebtedness (No. w14808). National Bureau of Economic Research.

Monticone, C. (2010). How much does wealth matter in the acquisition of financial literacy? Journal of Consumer Affairs, 44(2), 403-422.

Morgan, P. J., \& Trinh, L. Q. (2019). Determinants and impacts of financial literacy in Cambodia and Viet Nam. Journal of Risk and Financial Management, 12(1), 19.

Muñoz-Murillo, M., Álvarez-Franco, P. B., \& Restrepo-Tobón, D. A. (2020). The role of cognitive abilities on financial literacy: New experimental evidence. Journal of Behavioral and Experimental Economics, 84, 101482.

Murendo, C., \& Mutsonziwa, K. (2017). Financial literacy and savings decisions by adult financial consumers in Zimbabwe. International journal of consumer studies, 41(1), 95-103.

Moschis, G. P., \& Churchill Jr, G. A. (1978). Consumer socialization: A theoretical and empirical analysis. Journal of marketing research, 15(4), 599-609.

Parker, A. M., De Bruin, W. B., Yoong, J., \& Willis, R. (2012). Inappropriate confidence and retirement planning: Four studies with a national sample. Journal of Behavioral Decision Making, 25(4), 382-389.

Pires, V., \& Quelhas, A. P. (2015). Financial literacy among the higher education students: Empirical evidence for the Portuguese case. Portuguese journal of finance, Management and Accounting, 1(1).

Potrich, A. C. G., Vieira, K. M., \& Kirch, G. (2018). How well do women do when it comes to financial literacy? Proposition of an indicator and analysis of gender differences. Journal of Behavioral and Experimental Finance, 17, 28-41. 
Rai, K., Dua, S., \& Yadav, M. (2019). Association of financial attitude, financial behavior, and financial knowledge towards financial literacy: A structural equation modeling approach. FIIB Business Review, 8(1), 51-60.

Rasheed, M. H., Rafique, A., Zahid, T., \& Akhtar, M. W. (2018). Factors influencing investor's decision making in Pakistan. Review of Behavioral Finance.

Ringle, C. M., Sarstedt, M., Mitchell, R., \& Gudergan, S. P. (2020). Partial least squares structural equation modeling in HRM research. The International Journal of Human Resource Management, 31(12), 1617-1643.

Shim, S., Barber, B. L., Card, N. A., Xiao, J. J., \& Serido, J. (2010). Financial socialization of firstyear college students: The roles of parents, work, and education. Journal of youth and adolescence, 39(12), 1457-1470.

Shockey, S. S. (2002). Low-wealth adults' financial literacy, money management behaviors, and associated factors, including critical thinking (Doctoral dissertation, The Ohio State University).

Skagerlund, K., Lind, T., Strömbäck, C., Tinghög, G., \& Västfjäll, D. (2018). Financial literacy and the role of numeracy-How individuals' attitudes and affinity with numbers influence financial literacy. Journal of Behavioural and Experimental Economics, 74, 18-25.

Sohn, S. H., Joo, S. H., Grable, J. E., Lee, S., \& Kim, M. (2012). Adolescents' financial literacy: The role of financial socialization agents, financial experiences, and money attitudes in shaping financial literacy among South Korean youth. Journal of adolescence, 35(4), 969-980.

Stolper, O. A., \& Walter, A. (2017). Financial literacy, financial advice, and financial behavior. Journal of Business Economics, 87(5), 581-643.

Stone, M. (1974). Cross-validatory choice and assessment of statistical predictions. Journal of the Royal Statistical Society: Series B (Methodological), 36(2), 111-133.

Sundarasen, S. D. D., Rahman, M. S., Othman, N. S., \& Danaraj, J. (2016). Impact of financial literacy, financial socialization agents, and parental norms on money management. Journal of Business Studies Quarterly, 8(1), 137.

Tang, N., Baker, A., \& Peter, P. C. (2015). Investigating the disconnect between financial knowledge and behavior: The role of parental influence and psychological characteristics in responsible financial behaviors among young adults. Journal of Consumer Affairs, 49(2), 376-406.

US Department of the Treasury, (2008). The Department of the Treasury Blueprint for a Modernized Financial Regulatory Structure.

Ward, S. (1974). Consumer socialization. Journal of consumer research, 1(2), 1-14.

Wixom, B. H., \& Watson, H. J. (2001). An empirical investigation of the factors affecting data warehousing success. MIS quarterly, 17-41.

Xia, T., Wang, Z., \& Li, K. (2014). Financial literacy overconfidence and stock market participation. Social indicators research, 119(3), 1233-1245.

Zuhair, S., Wickremasinghe, G., \& Natoli, R. (2015). Migrants and self-reported financial literacy. International Journal of Social Economics. 